\title{
Field evaluation of Cavendish banana cultivars propagated either by suckers or by tissue culture, over six crop cycles in the tropics
}

\author{
Esendugue Greg FonSAH ${ }^{a *}$, Charles Agho AdAMU ${ }^{b}$, Blessed Ndokpe OKOLE ${ }^{c}$, Benjamin G. MuLLINIX ${ }^{d}$
}

a Dep. Agric. Appl. Econom., Univ. Georgia, Tifton,

GA 31793, USA

gfonsah@uga.edu

b Del Monte Fresh Produce SARL, BP 13275, Douala, Cameroon, West Africa

${ }^{\mathrm{C}}$ LifeLab (ECoBio Innovation Centre), PO Box 30603, Mayville 4058, Durban

KwaZulu-Natal, South Africa blessed.okole@Lifelab.org.za

d University of Georgia, Tifton Campus,Tifton, GA 31793-0748, USA

mullinix@uga.edu

${ }^{*}$ Correspondence and reprints

Received 24 May 2006 Accepted 21 February 2007

Fruits, 2007, vol. 62, p. 205-212 (C) 2007 Cirad/EDP Sciences All rights reserved DOI: 10.1051/fruits:2007016 www.fruits-journal.org RESUMEN ESPAÑOL, p. 212
Field evaluation of Cavendish banana cultivars propagated either by suckers or by tissue culture, over six crop cycles in the tropics.

Abstract - Introduction. Bananas are traditionally propagated by suckers: nevertheless, the advantage of using tissue-cultured plants for banana production has been demonstrated in recent years. Despite the large-scale use of micropropagated plants in the subtropical regions, little information is available on the performance of these crops in tropical countries. So we compared the yield potential of some Cavendish banana cultivars propagated either by traditional suckers or by tissue culture. Materials and methods. A randomized complete block experiment was established in a commercial plantation in Cameroon to compare the performance of three tissue-cultured banana plants of Grand Nain, Williams and Zelig cultivars and two conventionally-propagated plants of Grand Nain and Williams. Morphological, phenological and yield component data were collected for six crop cycles. Results. All the plants grew vigorously and produced quality exportable fruits. However, the tissue-cultured plants consistently produced heavier bunches and higher yields than the conventionally-propagated plants. The highest yields (65.92 $\mathrm{t} \cdot \mathrm{ha}^{-1}$ for Grand Nain, $64.60 \mathrm{t} \cdot \mathrm{ha}^{-1}$ for Williams and $65.58 \mathrm{t} \cdot \mathrm{ha}^{-1}$ for Zelig) were obtained for the tissue-cultured plants in the third crop cycle compared with $51.43 \mathrm{t} \cdot \mathrm{ha}^{-1}$ and $59.02 \mathrm{t} \cdot \mathrm{ha}^{-1}$ obtained for the traditionally-propagated Grand Nain and Williams plants, respectively. There were no significant yield differences between the plants of different origin in the second and fourth cycles, respectively. However, the tissue-cultured Williams and Zelig plants outperformed the other plants in the sixth crop cycle. Conclusion. The tissue-cultured plants of the three Cavendish cultivars studied performed better than the plants resulting from conventional suckers. The best cultivar for commercial plantation used, that is located in a tropical environment, was Williams. In general, to obtain an optimum benefit, we would recommend the use of tissue-cultured plants over a period of 6-7 years with good management practices.

Cameroon / Musa / varieties / plant propagation / propagation materials / ratooning / micropropagation / yields

\section{Évaluation, en zone tropicale et sur six cycles de récolte, de bananiers Cavendish propagés soit par rejets, soit par culture de tissus.}

Résumé - Introduction. Les bananiers sont traditionnellement propagés par rejets, néanmoins, l'avantage de l'utilisation de plants issus de micropropagation a été démontré en bananeraie au cours des dernières années. En dépit de l'utilisation à grande échelle de tels plants en régions subtropicales, peu d'informations sont disponibles sur les performances de tels bananiers dans les pays tropicaux. Nous avons donc comparé le potentiel de rendement de quelques cultivars de bananiers Cavendish propagés soit par rejets traditionnels, soit par culture de tissus. Matériel et méthodes. Une expérimentation en blocs complets randomisés a été mise en place dans une plantation commerciale du Cameroun pour comparer les performances de plants issus de la culture de tissus de trois cultivars de bananier (Grand Naine, Williams et Zelig) et de plants provenant de la multiplication traditionnelle de deux cultivars (Grande Naine et Williams). Des données morphologiques, phénologiques et de rendement ont été rassemblées sur six cycles de récolte. Résultats. Tous les plants se sont développés vigoureusement et ont produit des fruits de qualité exportable. Cependant, les plants issus de culture de tissus ont produit des régimes plus lourds et de meilleurs rendements que les plants d'origine conventionnelle. Les rendements les plus élevés $\left(65,92 \mathrm{t} \cdot \mathrm{ha}^{-1}\right.$ pour Grande Naine, $64,60 \mathrm{t} \cdot \mathrm{ha}^{-1}$ pour Williams et $65,58 \mathrm{t} \cdot \mathrm{ha}^{-1}$ pour Zelig) ont été obtenus pour les plants issus de micropropagation en troisième cycle de récolte, alors que les plants de Grande Naine et de Williams multipliés de façon traditionnelle ont alors donné, respectivement, $51,43 \mathrm{t} \cdot \mathrm{ha}^{-1}$ et $59,02 \mathrm{t} \cdot \mathrm{ha}^{-1}$. Il n'y pas eu de différences significatives de rendement entre les plants de différentes origines en deuxième et quatrième cycle. Cependant, les plants de Williams et de Zelig issus de culture de tissus ont été supérieurs aux autres plants lors du sixième cycle de récolte. Conclusion. Les plants issus de la micropropagation des trois cultivars de Cavendish étudiés ont eu de meilleures performances que les plants résultant de rejets conventionnels. Le meilleur cultivar de la plantation commerciale étudiée, située dans un environnement tropical, a été Williams. Pour obtenir globalement un résultat optimal, nous recommanderions d'utiliser des plants issus de la culture de tissus, sur 6 à 7 ans, en leur assurant de bonnes pratiques de gestion.

Cameroun / Musa / variété / multiplication des plantes / matériau de multiplication / multiplication par rejet de souche / micropropagation / rendement 


\section{Introduction}

Bananas and plantains are traditionally propagated by suckers. This propagation method is laborious, with very low multiplication rates and slow regeneration cycles of new suckers [1]. Furthermore, the prevalence of diseases and pests on banana planting materials (suckers) has generated the need for clean planting materials in large quantities for both small- and large-scale farmers. The advantage of using tissue-cultured plants for banana production has been demonstrated in recent years [2-4]. Propagation of banana plants by the in vitro shoottip culture technique was first reported by Ma and Shii [5]. From 1972 onwards, the technique of banana tissue culture has been refined for use by both commercial and research laboratories for multiplication of banana and plantain cultivars. A number of reviews have since been written on the application of in vitro culture techniques in bananas [2-4, 6].

In general, tissue-cultured plants have six important advantages over conventional planting material: (i) plants can be rapidly multiplied from a mother plant of known and superior genetic characteristics, (ii) plants can be provided to the grower free of important banana diseases and pests; (iii) plants produced under appropriate conditions will be true-to-type and conform to characteristics of the mother plant; (iv) plants have a better survival rate, especially under adverse climatic conditions; (v) plants have a higher yield and shorter period from planting to harvesting than conventional planting material, and (vi) plants have a uniform growth, resulting in synchronized harvest dates, which simplifies management practices [3, 7-10].

During the past decade, developing tropical nations have greatly expanded their agricultural production. Use of tissue-cultured banana plants as starting material for establishing new or poor-performing farms has now become a common practice for commercial plantations. Nevertheless, despite the large-scale use of tissue-cultured plants, only a few countries have accumulated sufficient data on the performance of these crops in tropical countries. The lack of infor- mation on the performance of tissue-cultured banana planting materials has, unfortunately, resulted in the late introduction of this technology into the tropics [1].

The goal of our investigation was to evaluate the yield potential of some 'Cavendish' banana cultivars used for commercial production and export to the EU market: three cultivars deriving from tissue culture and two cultivars resulting from conventional propagation through suckers. The study was carried out over six crop cycles in an experimental plot on a corporate banana plantation in Cameroon. The specific objectives of the experiment were to identify the best export Cavendish cultivar which could be recommended for tropical conditions, and to determine how long the selected tissue-cultured and conventional cultivars will continuously maintain optimum yield in the field before diminishing returns set in.

\section{Materials and methods}

\subsection{Banana cultivars and tissue culture procedure}

Three banana cultivars deriving from tissue culture (TC) were used for our trial: 'Grand Nain', 'Williams' and 'Zelig', belonging to the (AAA) 'Cavendish' group of desert banana. Micropropagated plants (TC Grand Nain, TC Williams and TC Zelig) were produced following a standard protocol outlined by Okole and Schulz [11]. Before being transferred to the field, the plants stayed in the nursery for 6 weeks until they reached the 20-cm stage. Approximately 500-600 plantlets were obtained from each meristem.

\subsection{Conventional sucker procedure}

Sword suckers of the two cultivars 'Grand Nain' and 'Williams' were removed from vigorous growing plants for conventional propagation and all roots were trimmed. During replanting in the field, these suckers were treated with a nematicide by applying $10 \mathrm{~g}$ of Counter 10G (ai: terbuphos 10\%, BASF AGRO SAS, France) in each hole. There were no conventional sword suckers 
for Zelig because this was a new variety introduced from Israel, and the commercial plantation chosen for our study had no such suckers.

\subsection{Field trial}

Our study was conducted from March 1993 to March 1997 in a commercial banana plantation located in the South-West Province of Cameroon in Central Africa (lat. $4^{\circ} \mathrm{N}$ ). The plantation chosen for the experiment is located in an old uplifted, slightly tilted and deserted coastal plain made up of thick layers of marine and deltaic soil deposits. A considerable portion of the surface sediments has been re-worked and re-deposited by fluvial action.

\subsection{Environmental conditions}

The area of the experimental plot has a typical tropical climate. The seasons are distinguished by a rainfall pattern with one rainy season from June through September with peaks higher than (500 to 600) $\mathrm{mm}$ in July and August, and one distinct dry season from December to mid-March with very little or no rainfall of $0-10 \mathrm{~mm}$. The months of April to May and October to November are periods of intermediate rainfall with 100 $200 \mathrm{~mm}$ per month. The total rainfall per year in the experimental area ranges from (1500 to 2000) $\mathrm{mm}$. The temperature is fairly constant throughout the year with an average of $27^{\circ} \mathrm{C}$. The average absolute minimum and maximum temperatures are about $22^{\circ} \mathrm{C}$ and $33^{\circ} \mathrm{C}$, respectively, and the average daily relative humidity is about $70 \%$. The soil texture in the experimental site ranges from coarse sandy clay loam to heavy clay loam, and the soil pH ranges from 5.0 to 5.5.

General farm management practices, such as fertilization, irrigation, weed control, deleafing, desuckering, and nematode and leaf spot disease control, were uniform and optimal throughout the experimental period. Urea $(46 \% \mathrm{~N})$ was applied at the rate of $60 \mathrm{~g} \cdot$ plant $^{-1}$, followed by ammonium sulfate $(21 \% \mathrm{~N})$ at the rate of $125 \mathrm{~g} \cdot \mathrm{plant}^{-1}$; biammonium phosphate $(18 \% \mathrm{~N}$ and $46 \%$ $\mathrm{P}_{2} \mathrm{O}_{5}$ ) at the rate of $120 \mathrm{~g} \cdot$ plant $^{-1}$ was also applied. This operation was repeated fol- lowing the same sequence on a monthly basis. Furthermore, potassium chloride $\left(\mathrm{KCI}, 60 \% \mathrm{~K}_{2} \mathrm{O}\right.$ ) at the rate of $125 \mathrm{~g} \cdot$ plant $^{-1}$ was applied every 6 weeks followed by one application per year of triple superphosphate (TSP, 38-48\% $\mathrm{P}_{2} \mathrm{O}_{5}$ ). Finally, dolomite (30\% $\mathrm{CaO}$ and $20 \% \mathrm{MgO}$ ) at the rate of $500 \mathrm{~g} \cdot$ plant $^{-1}$ was applied two times a year.

Irrigation was supplied by a pumping system with a capacity of $500 \mathrm{~m}^{3} \cdot \mathrm{h}^{-1}$ and Mancap undertree sprinklers installed $8.3 \mathrm{~m}$ apart and capable of supplying $160 \mathrm{~L} \cdot \mathrm{h}^{-1}$ per sprinkler. However, irrigation was applied three times a week at the rate of $16.7 \mathrm{~mm}$ each. Three different chemicals were used for weed control, Gramozone (paraquat), Roundup and Basta. Roundup 120 was applied at the rate of $1 \mathrm{~L} \cdot \mathrm{ha}^{-1}$ mixed in $100 \mathrm{~L}$ of $\mathrm{H}_{2} \mathrm{O}$ following a 5-week cycle. Thereafter, Gramoxone and Basta were applied following a 4-week interval each at the rate of $1 \mathrm{~L} \cdot \mathrm{ha}^{-1}$ mixed in $200 \mathrm{~L}$ of $\mathrm{H}_{2} \mathrm{O}$. Then, the sequence started again in a similar fashion. A deleafing operation was done once a week. Sucker pruning was done 6 times per year. For sigatoka control, Tilt (a.i. triazoles) at the rate of $0.41 \mathrm{~L} \cdot \mathrm{ha}^{-1}$, followed by Benlate (a.i. benzimidazoles) at the rate of $0.25 \mathrm{~L} \cdot \mathrm{ha}^{-1}$, followed by Bravo (a.i. chlorothanil) at the rate of $1.75 \mathrm{~L} \cdot \mathrm{ha}^{-1}$ and Calixin (a.i. tridemorph) at the rate of $0.6 \mathrm{~L} \cdot \mathrm{ha}^{-1}$ were used. Depending on the disease pressure, 8-12 sprays per year were performed [1].

\subsection{Experimental design}

Our experiment was carried out using a randomized complete block design with four replications. The plot size was $20 \mathrm{~m} \times 20 \mathrm{~m}$. All the five different planting materials (conventional and micropropagated cultivars) were planted at a distance of $2.54 \mathrm{~m} \times$ $2.16 \mathrm{~m}$, equidistant triangular, with a population of 1850 plants ha $^{-1}$. The conventional suckers of Grand Nain (CP Grand Nain) and Williams (CP Williams) were included in the randomized complete block design. Each cultivar had one plant per replication with a guard row on each side. All the data of the five treatments were analyzed using a mixed model analysis. Mean separation between cultivars was done using 


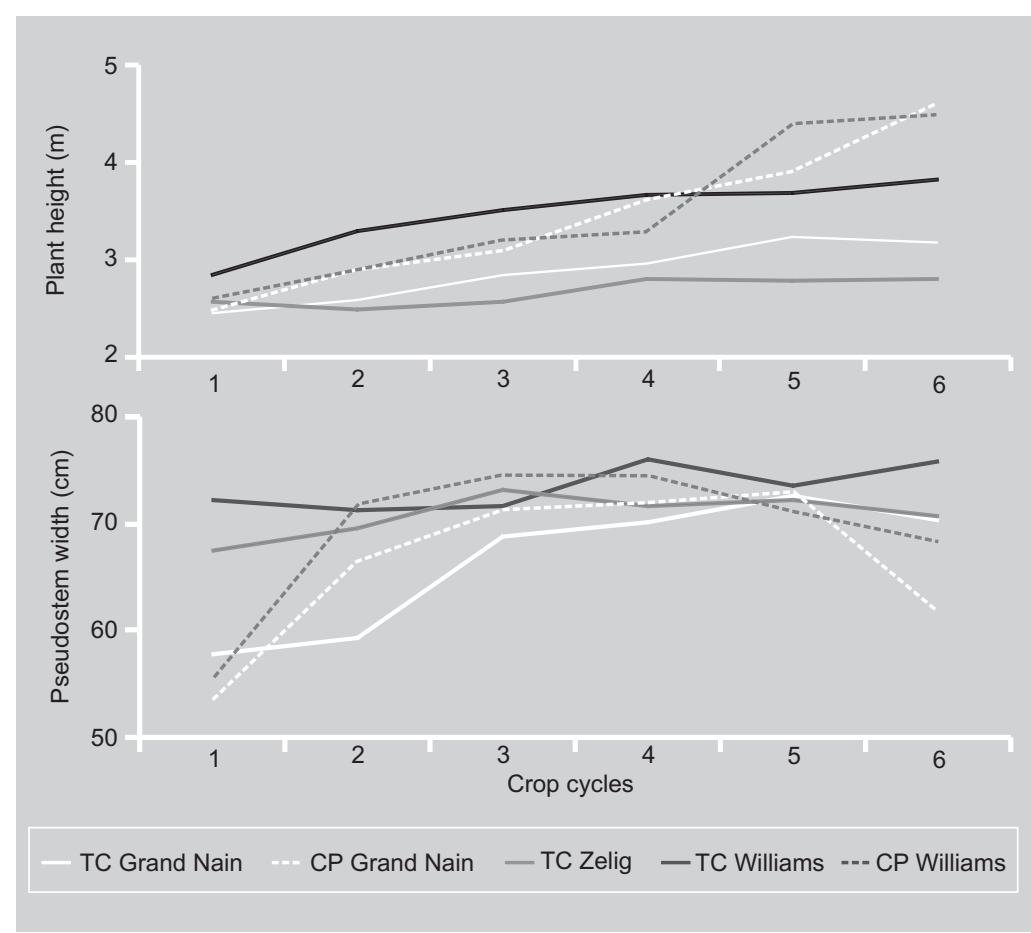

Figure 1.

Plant height and pseudostem width measured $30 \mathrm{~cm}$ above the ground for three tissuecultured and two conventionally-propagated cultivars over six crop cycles (Cameroon, March 1993March 1997).
LSD at $P=0.05$. $P$ values lower than 0.05 were considered significant.

\subsection{Data collection}

During the trial, data collected at the time of flowering were the plant height (measured from the ground level to the neck of the inflorescence), pseudostem circumference measured $30 \mathrm{~cm}$ above the ground, and the shooting date; data collected during harvest were the bunch weight (after removal of the last two hands and the male inflorescence), finger length of the second basal hand, number of hands per bunch, and yield. The caliper grade was also registered.

\section{Results and discussion}

\subsection{Plant characteristics}

Both conventionally-propagated Williams (CP Williams) and Grand Nain (CP Grand Nain) plants had, on average, the tallest plants in the fifth and sixth crop, whereas plants resulting from tissue culture of the Zelig cultivar (TC Zelig) had the shortest plant height on average in all the crop cycles (figure 1). The average plant height in all the six crop cycles was around $3.48 \mathrm{~m}$ for $\mathrm{CP}$ Williams, $3.47 \mathrm{~m}$ for plants resulting from tissue culture of Williams, $3.43 \mathrm{~m}$ for $\mathrm{CP}$ Grand Nain, $2.88 \mathrm{~m}$ for TC Grand Nain and $2.67 \mathrm{~m}$ for TC Zelig.

The pseudostem width increased progressively with plantation age. During the plant crop stage, the pseudostem width was $72.30 \mathrm{~cm}$ for TC Williams, $67.43 \mathrm{~cm}$ for TC Zelig, $57.75 \mathrm{~cm}$ for TC Grand Nain, $53.50 \mathrm{~cm}$ for CP Grand Nain and $55.50 \mathrm{~cm}$ for CP Williams (figure 1). In the sixth crop cycle, CP Grand Nain and CP Williams had the smallest pseudostem width, while TC William had the biggest (figure 1).

\subsection{Bunch components and annual yield}

The results of the bunch mass and its components for the two conventionally-propagated (CP) cultivars and the three cultivars resulting from tissue culture (TC) over the six crop cycles show that the average bunch weight after removal of the last two hands was around $31.78 \mathrm{~kg}$ for TC Grand Nain, $32.52 \mathrm{~kg}$ for TC Williams, $32.56 \mathrm{~kg}$ for TC Zelig, $30.51 \mathrm{~kg}$ for CP Williams and $31.58 \mathrm{~kg}$ for CP Grand Nain. Furthermore, in the third crop cycle, the three cultivars resulting from tissue culture produced the heaviest bunches and significantly outperformed the two conventionally-propagated cultivars (figure 2). This result normally occurs around 2 years after planting 20 -cm tissue-cultured plants in the field. In the sixth crop cycle, TC Williams plants still produced the heaviest bunches, although the bunch weight of all other cultivars decreased. On average for all six crop cycles, TC Zelig dominated with $32.55 \mathrm{~kg}$ bunch weight, followed by TC Williams with $32.52 \mathrm{~kg}$.

Our experiment results show that plants resulting from tissue culture grow faster and produce better yields than conventionallypropagated plants [1]. This confirms the results published by Israeli et al. [12] and Vuylsteke and Ortiz [13], who reported the 
same observations. Plant height is a measure of plant vigor, which indicates that tissuecultured plants are cleaner than conventionally-propagated plants and already possess an active root and shoot system at planting. This could result in quicker establishment, more vigorous growth and shorter production cycles [7, 12-13] of these tissue-cultured plants. Pseudostem width and plant height have a direct correlation with the plant stability. Banana cultivars that are shorter with larger pseudostem circumferences have been reported to be more resistant to wind damage [15]. We also observed such a characteristic in our experiment.

A trend found for the bunch weight was also observed for the number of hands per bunch. The highest number of hands per bunch was found in the third crop cycle for all the cultivars, except for conventionallypropagated Williams, which had its peak in the fourth crop cycle (figure 2). The same plants (CP Williams) outperformed all the other cultivars in the sixth crop cycle, with 9.4 hands. The least number of hands was observed for TC Grand Nain, which had only 7.97 hands (figure 2).

For the finger length, there was no specific pattern found between the five cultivars in the different crop cycles, although, on average, $\mathrm{CP}$ Williams outperformed all the other cultivars: in the sixth crop cycle, finger length of CP Williams was $27.3 \mathrm{~cm}$; then, finger length of CP Grand Nain was $25.4 \mathrm{~cm}$; TC Williams, $25.03 \mathrm{~cm}$; TC Grand Nain, $24.6 \mathrm{~cm}$; and TC Zelig, $24.25 \mathrm{~cm}$ (figure 2).

Fruit maturity is usually related to the diameter or grade of the finger, known in banana terminology as "calibration", and hence an estimate of the bunch maturity can be made. In commercial practices, finger diameter or harvest grade is determined by measuring the middle finger in the outer whorl of the second hand at the thickest part of the finger on each bunch [16].

Our results showed that, in the first crop cycle, the caliper grade of TC Grand Nain was $45.93 \mathrm{~mm}$; CP Grand Nain, $45.70 \mathrm{~mm}$; TC Zelig, $45.25 \mathrm{~mm}$; CP Williams $44.80 \mathrm{~mm}$; and TC Williams, $43.80 \mathrm{~mm}$. In the third crop cycle, there was no significant difference in the caliper grade of all the five cultivars although CP Grand Nain had the least,
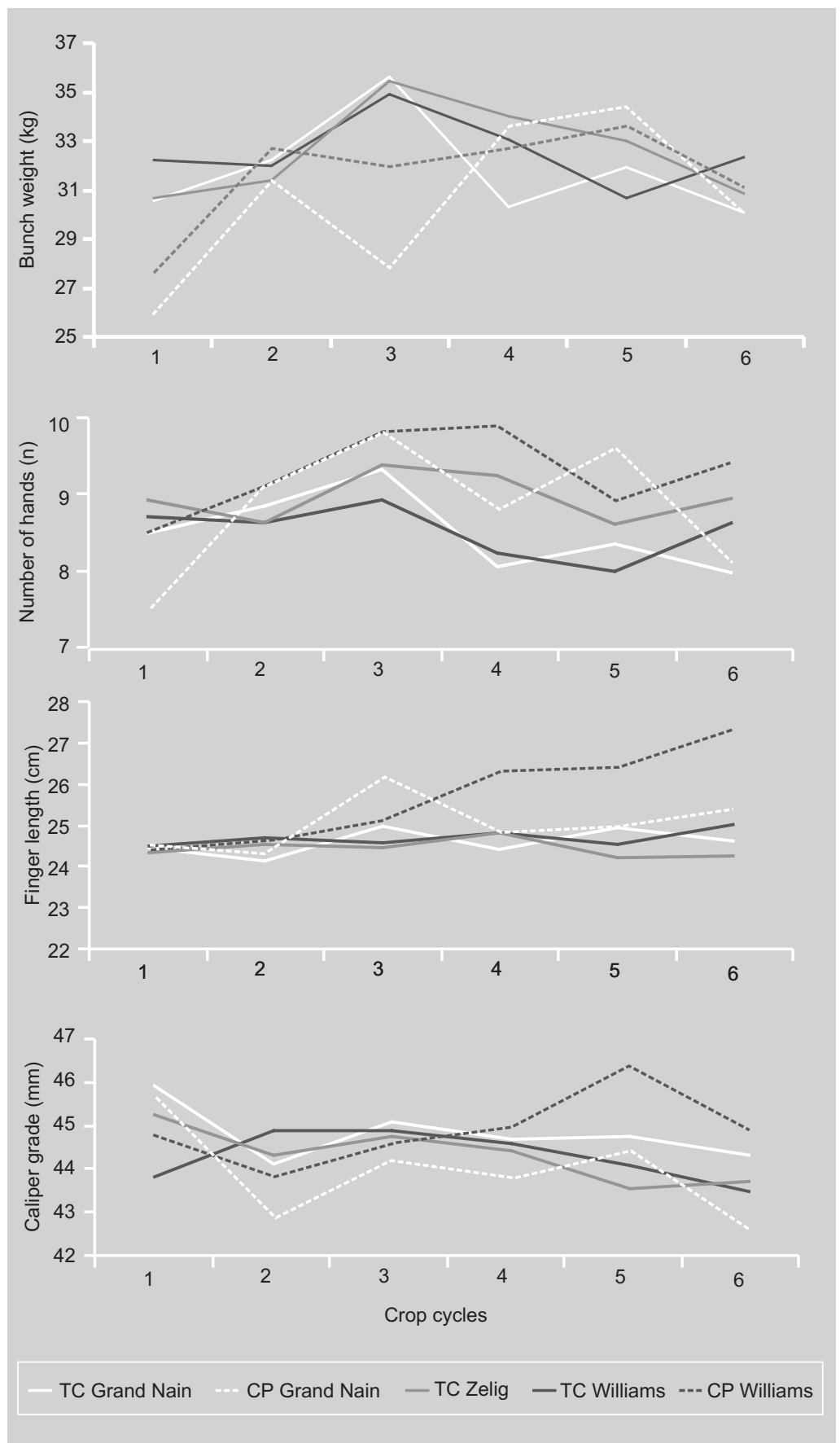

$44.2 \mathrm{~mm}$. Thus, CP Williams outperformed all four cultivars in the fifth and sixth crop cycles, respectively (figure 2).

After the first crop, the yield of the five cultivars studied started increasing (table I) and, in the third crop, the three cultivars obtained from tissue culture (TC)
Figure 2.

Bunch weight, number of hands, finger length and caliper grade for three tissue-cultured and two conventionallypropagated cultivars over six crop cycles (Cameroon, March 1993-March 1997). 


\section{Table I.}

Yield data $\left(\mathrm{t} \cdot \mathrm{ha}^{-1}\right)$ of three tissue-cultured (TC) and two conventionally-propagated (CP) planting materials over six crop cycles in the tropics (Cameroon), March 1993-March 1997.

\begin{tabular}{lccccccc}
\hline Cultivar & Cycle 1 & Cycle 2 & Cycle 3 & Cycle 4 & Cycle 5 & Cycle 6 & Mean \\
TC Grand Nain & $56.52 \mathrm{~b}$ & $59.62 \mathrm{a}$ & $65.92 \mathrm{a}$ & $56.12 \mathrm{~b}$ & $59.02 \mathrm{bc}$ & $55.59 \mathrm{~b}$ & $58.80 \mathrm{~b}$ \\
TC William & $59.57 \mathrm{a}$ & $59.16 \mathrm{a}$ & $64.60 \mathrm{a}$ & $61.16 \mathrm{a}$ & $56.70 \mathrm{c}$ & $59.80 \mathrm{a}$ & $60.17 \mathrm{a}$ \\
TC Zelig & $56.70 \mathrm{~b}$ & $58.04 \mathrm{a}$ & $65.58 \mathrm{a}$ & $62.90 \mathrm{a}$ & $61.10 \mathrm{ab}$ & $57.07 \mathrm{ab}$ & $60.23 \mathrm{a}$ \\
CP Grand Nain & $47.92 \mathrm{~d}$ & $58.09 \mathrm{a}$ & $51.43 \mathrm{c}$ & $62.16 \mathrm{a}$ & $63.64 \mathrm{a}$ & $55.50 \mathrm{~b}$ & $56.46 \mathrm{c}$ \\
CP Williams & $50.88 \mathrm{c}$ & $60.50 \mathrm{a}$ & $59.02 \mathrm{~b}$ & $60.50 \mathrm{a}$ & $62.16 \mathrm{a}$ & $57.54 \mathrm{ab}$ & $58.43 \mathrm{~b}$
\end{tabular}

$\operatorname{LSD}(0.05)=2.83$ (each cycle); $\operatorname{LSD}(0.05)=1.16$ (cycle mean)

outperformed the two cultivars resulting from conventional propagation (CP). For instance, the highest yield was $65.92 \mathrm{t} \cdot \mathrm{ha}^{-1}$ for TC Grand Nain, $65.58 \mathrm{t} \cdot \mathrm{ha}^{-1}$ for TC Zelig and $64.60 \mathrm{t} \cdot \mathrm{ha}^{-1}$ for TC Williams compared with $51.43 \mathrm{t} \cdot \mathrm{ha}^{-1}$ for CP Grand Nain and $59.02 \mathrm{t} \cdot \mathrm{ha}^{-1}$ for $\mathrm{CP}$ Williams. After the third crop, there was a gradual decline for all the cultivars, except for CP Grand Nain, which maintained a steady increase in the fourth and fifth crop cycles before declining. The best mean yields over the six crop cycles were $60.23 \mathrm{t} \cdot \mathrm{ha}^{-1}$ for TC Zelig and $60.17 \mathrm{t} \cdot \mathrm{ha}^{-1}$ for TC Williams (table I).

The variations in yield among the five cultivars obtained after the third crop cycle could be due to genetic diversity of the clones and also to environmental conditions in the plantation. This is a common phenomenon observed with hardy, tolerant cultivars and it is one of the reasons why TC Williams is much preferred to the other four cultivars in the plantation studied. Higher yields after the plant crop harvest in a commercial plantation is very important in order to have fruits on a weekly basis for the export market. In our study, it was observed that the benefits of plants resulting from tissue culture could only be achieved with efficient management practices and good environmental conditions. These factors could be the major reason why banana yield varies between different countries.

The performance of tissue-cultured banana plants in different planting regions over many crop cycles has not been extensively investigated in the tropics. Most of the reported yield data are from subtropical banana-growing countries. These latest results differ considerably from those from tropical areas. Some of the results obtained from subtropical countries cannot be implemented in tropical countries. For example, in subtropical countries, around 13-16 months are necessary from planting to harvest for the Cavendish cultivars such as TC Grand Nain, TC Williams and TC Zelig (Robinson et al. [8]), whereas, in tropical countries, because of the favorable climatic conditions, this time is shortened to $8-10$ months for the same cultivars to be harvested.

From our trials, we found that the mean yield of tissue-cultured plants, especially TC Williams and TC Zelig, was significantly higher than that of plants resulting from conventional propagation through suckers (table I). Vuylsteke and Ortiz [13] reported no significant difference in plantain yield between tissue-cultured and conventional planting material. Most of the results reported in the literature were only for the plant crop or the first ratoon crop (R1 crop) and, from our results, it was reported that significant yield differences between conventionally-propagated plants and tissuecultured plants were obvious. The increase in yield in all the crop cycles and, in particular, in the first cycle is very important to the farmer to enable him/her to recover his/her initial high cost of investment.

The cultivar TC Zelig performed very well in our experiment during the warm months. However, under stressful environmental conditions (poor irrigation, low temperature 
and poor soils), there was choking and curvature of the fruits. Tropical countries usually have fluctuating environmental conditions and, out of the five cultivars studied, the level of tolerance to stress in our trial was as follows: TC Williams > TC Grand Nain > TC Zelig > CP Williams and CP Grand Nain. The cultivar TC Zelig, therefore, has little potential in many tropical plantations. It could be used as a planting material only in well-managed plantations.

\section{Conclusions}

From our study, we found that the tissuecultured planting materials of the three Cavendish cultivars studied performed better than the two cultivars resulting from planting materials conventionally propagated through suckers. The best cultivar for the commercial plantation used, that is located in a tropical environment, was TC Williams, although the other cultivars TC Grand Nain and TC Zelig also performed well. The cultivar CP Grand Nain had the tallest plant height in the sixth crop, followed by CP Williams. The shortest plants in all the crop cycles was those of TC Zelig. The heaviest bunches of the three cultivars resulting from tissue culture were found in the third cycle, whereas conventionally-propagated Grand Nain and Williams plants had the lowest bunch weight.

In the same way, the highest number of hands per bunch was found in the third crop cycle for four out of the five cultivars studied. The finger length had no correlation over the different crop cycles for all these five cultivars. In general, to obtain an optimum benefit, we would recommend the use of tissue-cultured plants over a period of 6 7 years with good management practices.

\section{Acknowledgement}

The authors are indebted to Dr. Karl Kunert, Professor, Forestry and Agricultural Biotechnology Insitute (FABI), University of Pretoria, South Africa and Dr. Richard Wallace, Professor \& Interim Department Head,
Department of Chemistry and Physics, Armstrong Atlantic State University, for their reviewing and insightful comments, and to Alice H. Pitts.

\section{References}

[1] Fonsah E.G., Chidebelu S.N., Economics of banana production and marketing in the tropics, Minerva Press, London, UK, 1995.

[2] Israeli Y., Lahav E., Reuveni O., In vitro culture of bananas, in: Gowen S. (Ed.), Bananas and plantains, Chapman and Hall, London, UK, 1995.

[3] Robinson J.C., Bananas and plantains, CAB International, Oxon, UK, 1996.

[4] Vuylsteke D., Shoot-tip culture for the propagation, conservation, and exchange of Musa germplasm. Practical manuals for handling crop germplasm in vitro, Int. Board Plant Genet. Resour. (IBPGR), Rome, Italia, 1989, $55 \mathrm{p}$.

[5] Ma S.S., Shii C.T., In vitro formation of adventitious buds in banana shoot apex following decapitation, J. Chin. Soc. Hortic. Sci. 18 (1972) 135-142.

[6] Daniells J.W., Comparison of growth and yield of bananas derived from tissue culture and conventional planting material, Banan. Newsl. 11 (2) (1988).

[7] Drew R.A., Smith M.K., Field evaluation of tissue-cultured bananas in South Eastern Queensland, Austral. J. Exp. Agric. 30 (1990) 569-574.

[8] Robinson J.C., Fraser C., Eckstein K., A field comparison of conventional suckers with tissue culture banana planting material over three crop cycles, J. Hortic. Sci. 68 (1993) 831-836.

[9] Arias O., Valverde M., Producción y variación somaclonal de plantas de banano variedad Grande Nain producidas por cultivo de tejidos, Rev. Asoc. Banan. Nac. (Costa Rica) 28 (1987) 6-11.

[10] Stover R.H., Simmonds N.W., Bananas, Longman Sci. Tech., Trop. Agric. Series, John Wiley \& Sons, New Yorkn USA, 1987.

[11] Okole B.N., Schulz F.A., Micro-cross sections of banana and plantains (Musa spp.) morphogenesis and regeneration of callus and shoot buds, Plant Sci. 116 (1996) 185195. 
[12] Israeli Y., Reuveni O., Named N., Genetic variability and performance of in vitro propagated banana plants, in: Cháves J.A., Calderón R.R. (Eds.), Memorias 1986 de la IV Reunión sobre agrofisiología del banano, Asoc. Banan. Nac., San José, Costa Rica, 1988, 97-104.

[13] Vuylsteke D., Ortiz R., Field performance of conventional vs. in vitro propagules of plantain (Musa spp., AAB group), HortScience 31 (1996) 862-865.

[14] Zamora A.B., Damasco O.P., Estano E.S., Barba R.C., Pateña L.F., Growth and yield of micropropagated and sucker-derived banana plants (Musa spp., cvs. Lakatan, Bungulun and Saba), Philipp. Agric. 72 (1989) 458-465.

[15] Robinson J.C., Nel D.J., Eckstein K., A field comparison of ten Cavendish sub-group banana cultivars and selections (Musa AAA) over four crop cycles in the subtropics, J. Hortic. Sci. 68 (1993) 511-521.

[16] Anon., La qualité de la banane, Inst. Rech. Fruits Agrumes (IRFA), Minist. Agric. Serv. Repress. Fraud. Contrôle Qual., Paris, France, 1980.

\section{Evaluación, en zona tropical y en base de seis ciclos de cosecha, de bananos Cavendish propagados o bien mediante brotes, o bien mediante cultivo de tejidos.}

Resumen - Introducción. Los bananos se propagan tradicionalmente mediante brotes. No obstante, la ventaja del uso de plántulas provenientes de micropropagación se demostró en bananales a lo largo de los últimos años. A pesar del uso a gran escala de tales plántulas en regiones subtropicales, la información referente a los rendimientos de tales bananos en los países tropicales es aún escasa. Por ello hemos comparado el potencial de rendimiento de algunos cultivares de bananos Cavendish propagados o bien mediante brotes tradicionales, o bien mediante cultivo de tejido. Material y métodos. Se puso en pie un experimento en bloques completos randomizados en una plantación comercial del Camerún para poder comparar los rendimientos de plántulas procedentes del cultivo de tejido de tres cultivares de banano (Grande Naine, Williams y Zelig) y las plántulas procedentes de la multiplicación tradicional de dos cultivares (Grande Naine y Williams). Se recopilaron datos morfológicos, fenológicos y de rendimiento en seis ciclos de cultivo. Resultados. Todas las plántulas se desarrollaron vigorosamente y produjeron frutos de una calidad apta para la exportación. Sin embargo las plántulas procedentes de cultivo de tejidos produjeron regímenes más pesados así como unos rendimientos mejores a aquellos mostrados por las plántulas de origen convencional. Los rendimientos más elevados $\left(65,92 \mathrm{t} \cdot \mathrm{ha}^{-1}\right.$ para el banano Grande Naine, $64,60 \mathrm{t} \cdot \mathrm{ha}^{-1}$ para Williams y $65,58 \mathrm{t} \cdot \mathrm{ha}^{-1}$ para Zelig) se obtuvieron para las plántulas procedentes de micropropagación en tercer ciclo de cosecha, mientras que las plántulas de banano Grande Naine y de Williams multiplicadas de modo tradicional dieron, respectivamente, $51,43 \mathrm{t} \cdot \mathrm{ha}^{-1}$ y $59,02 \mathrm{t} \cdot \mathrm{ha} \mathrm{H}^{-1}$. No hubo diferencias de rendimiento significantes entre plántulas de origen diferente en el segundo y en el cuarto ciclo. No obstante, las plántulas de Williams y de Zelig procedentes de cultivo de tejido fueron superiores a las otras plántulas para el sexto ciclo de cosecha. Conclusión. Las plántulas procedentes de la micropropagación de tres cultivares de Cavendish estudiados tuvieron mejores rendimientos que aquellas plántulas que resultaron de brotes convencionales. Williams fue el mejor cultivar de la plantación comercial estudiado, situado en un entorno tropical. Con el fin de lograr globalmente un resultado óptimo, recomendaríamos el empleo de plántulas procedentes del cultivo de tejidos, de ( 6 a 7) años, garantizando a la vez unas buenas prácticas de gestión.

Camerún / Musa / variedades / propagación de plantas / materiales de propagación / utilización de renuevas de la raíz / micropropagación / rendimiento 